\title{
Effect of Dichloromethane-Methanol Extract and Tomentin Obtained from Sphaeralcea angustifolia Cell Suspensions in a Model of Kaolin/Carrageenan-Induced Arthritis
}

\section{(1)(1) $\circledast$}

Authors

María del Pilar Nicasio-Torres, Jade Serrano-Román, Juanita Pérez-Hernández, Enrique jiménez-Ferrer, Maribel Herrera-Ruiz

\section{Affiliation}

Centro de Investigación Biomédica del Sur (CIBIS), Instituto Mexicano del Seguro Social (IMSS), Xochitepec, Morelos, México

Key words

Sphaeralcea angustifolia, Malvaceae, anti-inflammatory, arthritis, coumarins, scopoletin.

received 15.11.2016

revised $\quad 27.03 .2017$

accepted 28.03.2017

Bibliography

DOI https://doi.org/10.1055/s-0043-108760

Planta Med Int Open 2017; 4: e35-e42

(c) Georg Thieme Verlag KG Stuttgart · New York

ISSN 2509-9264

Correspondence

Dr. María del Pilar Nicasio-Torres

Centro de Investigación Biomédica del Sur (CIBIS)

Instituto Mexicano del Seguro Social (IMSS)

Argentina \#1

Col. Centro

62790 Xochitepec, Morelos

México

Tel.: + 52/777/361 2155, Fax: + 52/777/361 2155

pisaliva@yahoo.com.mx

Dr. Maribel Herrera-Ruiz

Centro de Investigación Biomédica del Sur (CIBIS)

Instituto Mexicano del Seguro Social (IMSS)

Argentina \#1

Col. Centro
62790 Xochitepec, Morelos

México

Tel.: + 52/777/361 2155, Fax: +52/777/361 2155

cibis_herj@yahoo.com.mx

Supporting information $1 \mathrm{H}$ NMR spectra of tomentin, HPLC chromatograms of SaDM extract, tomentin, and sphaeralcic acid, and a curve of tomentin doses and joint edema size are available online at http://www.thieme-connect.de/products.

\begin{abstract}
Cell suspension cultures from Sphaeralcea angustifolia produce compounds with anti-inflammatory activity, including scopoletin, tomentin, and sphaeralcic acid. Antiarthritic activity of scopoletin isolated from S. angustifolia and Erycibe obtusifolia wild plants was demonstrated in a complete Freud's adjuvant-induced arthritis model. In this project, the dichloromethane-methanol extract and tomentin isolated from S. angustifolia cell suspension were evaluated in mice using a kaolin/ carrageenan-induced arthritis model. After 9 days of treatment, the anti-inflammatory effect of $S$. angustifolia dichloromethane-methanol extract was $72 \%$ at a dose of $100 \mathrm{mg} / \mathrm{kg}$, a recovery of $55 \%$ was observed with methotrexate $(5.0 \mathrm{mg} / \mathrm{kg})$, and the anti-inflammatory effect for tomentin was dose-dependent with a median effective dose of $10.32 \mathrm{mg} / \mathrm{kg}$. The concentration of pro-inflammatory cytokines interleukin-1 $\beta$ and tumor necrosis factor alpha in the left joint of groups treated with S. angustifolia dichloromethane-methanol extract and tomentin at different doses was significantly lower than that detected in the group damaged with kaolin/carrageenan, and the concentration of interleukin-10 and interleukin-4 (anti-inflammatory cytokines) was significantly higher. The drop in mean body weight of mice treated with methotrexate $(-4.34 \pm 0.47 \mathrm{~g})$ was higher in comparison with the kaolin/carrageenan group $(-2.40 \pm 0.29 \mathrm{~g})$. On the other hand, the mean body weight of mice treated with $\mathrm{S}$. angustifolia dichloromethanemethanol extract $(-1.19 \pm 0.17 \mathrm{~g})$ was similar, and mice treated with tomentin $(0.19 \pm 0.11 \mathrm{~g})$ was lower. The dichloromethane-methanol extract and tomentin isolated from $\mathrm{S}$. angustifolia diminished joint edema induced by kaolin/carrageenan, possibly by acting as an immunomodulatory of the inflammatory response.
\end{abstract}

\begin{tabular}{|c|c|}
\hline BW & body weight \\
\hline CFE & $\lambda$-carrageenan footpad edema \\
\hline CFA & complete Freud's adjuvant \\
\hline $\mathrm{ED}_{50}$ & median effective dose \\
\hline IL & interleukin \\
\hline $\mathrm{K} / \mathrm{C}$ & kaolin/carrageenan \\
\hline MS & Murashige and Skoog \\
\hline & physiological saline solution \\
\hline
\end{tabular}

SaDM Sphaeralcea angustifolia dichloromethane-methanol

TPA 12-O-tetradecanoyl phorbol-13-acetate

\section{Introduction}

Rheumatoid arthritis is a progressive and chronic autoimmune disease that causes systemic damage and that may occur in all ages, although it entertains a high prevalence in middle age. The joints 
(synovial) are the most affected system, but the joints are also capable of disturbing other organs, such as the kidneys and lungs, among others. The disease develops as a painful condition, with loss of function and mobility. Later, the damage dimension is considerable since the quality of life of patients is diminished and enormous disability is caused [1].

Treatment of patients with this illness is based on the use of disease-modifying antirheumatic drugs and entertains the goal of diminishing the symptoms and preventing structural damage and disability; examples of these groups include etanercept, adalimumad, and methotrexate. Also, nonsteroidal anti-inflammatory drugs and glucocorticoids are employed. However, all of these drugs present several toxicity effects such as hepatotoxicity, myelosuppression, and an elevated risk of infections (bacterial and viral) [2]. There is a need for new treatments with the possibility of decreasing the collateral toxic effects of chronic therapy for rheumatoid arthritis, thereby improving the life quality of patients.

Fresh aerial tissues of Sphaeralcea angustifolia (Cav.) G. Don (Malvaceae) are employed to treat inflammatory processes [3-5]. The dichloromethane extract from the aerial tissues of this species was active in TPA-induced mouse ear edema, CFE in mice, and CFA-induced arthritis in rats. Scopoletin ( $\triangleright$ Fig. 1) was the active compound detected in the extract [6-8]. Since the collection of S. angustifolia plants from their natural habitat is restricted by the Mexican ministry of the environment and natural resources (SEMARNAT, NOM-059-ECOL-2001), the cell suspension culture of this species was established to produce the bioactive compound. Cell suspension developed in MS medium, with the total nitrate concentration reduced to $2.74 \mathrm{mM}$, produces the anti-inflammatory compounds ( Fig. 1) scopoletin, tomentin, and sphaeralcic acid [9]. Intraperitoneal administration $(100 \mathrm{mg} / \mathrm{kg}$ ) of the dichloromethane extract from the medium $(42 \pm 3 \%)$ and the dichloromethane-methanol extract from the biomass ( $39 \pm 9 \%$ ) of the $S$. angustifolia cell suspension showed a similar anti-inflammatory effect on CFE. The dichloromethane-methanol (9:1, v/v) extract (SaDM) from the biomass exerted a dose-dependent inhibitory effect with an $\mathrm{ED}_{50}$ of $137.63 \mathrm{mg}$ per $\mathrm{kg}$ on CFE [10]. The SaDM extract from the biomass ( $2.0 \mathrm{mg}$ per ear) was also inhibited by TPA-induced mouse ear edema by $78 \%$ [9]. Tomentin and sphaeralcic acid were active in both acute inflammatory models: the anti-inflammatory effects on
CFE at a dose of $45.0 \mathrm{mg} / \mathrm{kg}$ via the intraperitoneal route was $67 \%$ for sphaeralcic acid and $62 \%$ for tomentin. TPA-induced mouse ear edema was inhibited by sphaeralcic acid $(87 \pm 3 \%)$ and tomentin $(48 \pm 7 \%)$ to $1.0 \mathrm{mg}$ per ear. The effect of sphaeralcic acid was dosedependent with an $\mathrm{ED}_{50}$ of $93 \mathrm{mM}$ [9]. The anti-inflammatory $(52 \%$, $0.50 \mathrm{mg} /$ ear) and antiarthritic effects of scopoletin isolated from S. angustifolia and Erycibe obtusifolia Benth. (Convolvulaceae) wild plants have already been reported $[8,11]$. The cell suspension comprises a controlled culture with a high-quality production of scopoletin, tomentin, and sphaeralcic acid and is useful as an alternative for obtaining standardized extracts and for isolating compounds, with the purpose to carry out their evaluation in a $\mathrm{K} / \mathrm{C}$-induced arthritis animal model and to advance in the knowledge of its beneficial effects.

\section{Results}

The antiarthritic activity of SaDM extract and tomentin were evaluated in an arthritis model in mice induced with $\mathrm{K} / \mathrm{C}$ for a period of 10 days. In this arthritis model, oral administration of vehicle $1 \%$ Tween 20 (negative control) presented an increasing development of joint edema from the application of immunogens. Maximal inflammation was obtained on day 3 and this edema remained until day 9 ( $>$ Fig. 2). The animals were lethargic and had difficulty walking; the legs of the majority of these were fissured and secreted a thick yellowish liquid. Tissue inflammation was evaluated as a percentage with respect to baseline size. On day 9 after the induced damage, the joint increased its size by $2.25 \mathrm{~mm}$; this parameter was considered $100 \%$ of inflammation ( $\triangleright$ Table 1 ). In the PSS group, mice not receiving $\mathrm{K} / \mathrm{C}$, develop edema until day 1 , which was lower $(0.55 \pm 0.08)$ than that developed by the negative control. Additionally, inflammation decreased with time and the animals recovered the initial size of their joints ( $\triangleright$ Fig. 2 ).

In the mouse group treated with $5.0 \mathrm{mg} / \mathrm{kg}$ per day of methotrexate, maximal inflammation developed at day 2 and continued to be evident at day 4. After this time, edema was continuously reduced until day 9 of treatment ( $\triangleright$ Fig. 2 and $\triangleright$ Table 1 ). The mice demonstrated no difficulty in supporting their legs and walking. In the group treated with $100.0 \mathrm{mg} / \mathrm{kg}$ of SaDM extract daily, inflammation remained constant for 3 days, and from day 4 , the inflam-<smiles>[R]c1cc2oc(=O)ccc2c([R])c1OC</smiles><smiles>COc1c(C)cc2c(C(C)C)cc(C(=O)O)c(O)c2c1O</smiles>

Scopoletin $R_{1}=\mathrm{H}, R_{2}=\mathrm{OH}$

Tomentin $R_{1}=\mathrm{OH}, R_{2}=\mathrm{OCH}_{3}$ Sphaeralcic acid

Fig. 1 Chemical structures scopoletin, 7-hydroxy, 6-methoxycoumarin; tomentin, 5-hydroxy-6,7-dimethoxycoumarin; and sphaeralcic acid, 2-(1,8-dyhidroxy-4-isopropyl-6-methyl-7-methoxy) naphthoic acid. 


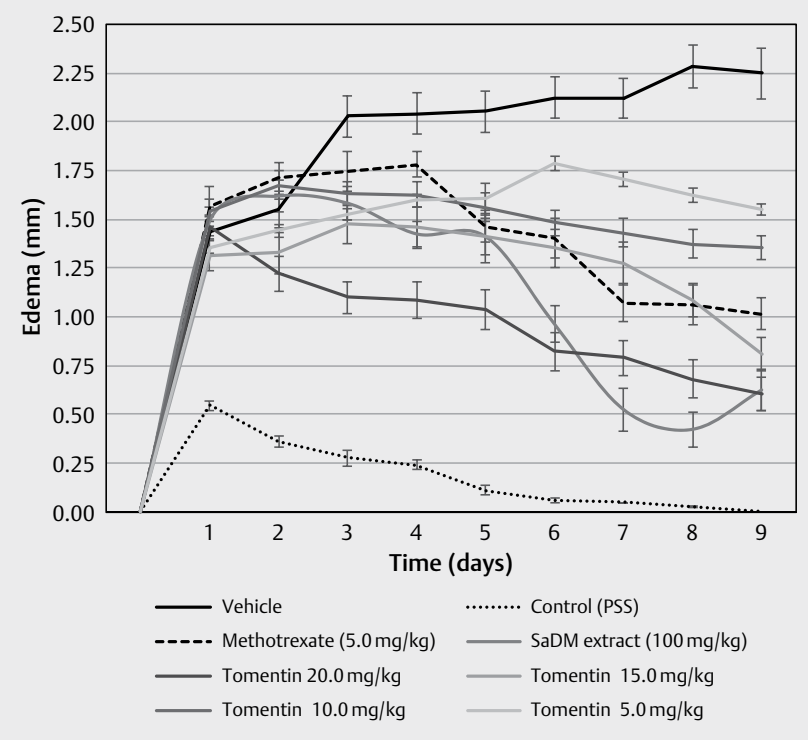

> Fig. 2 Effect of oral administration of methotrexate $(5.0 \mathrm{mg} / \mathrm{kg})$, SaDM extract, and tomentin $(5.0,10.0,15.0$, and $20.0 \mathrm{mg} / \mathrm{kg})$ on left joint size in mouse arthritis model induced with $\mathrm{K} / \mathrm{C}$.

- Table 1 Effect of SaDM extract from the biomass of S. angustifolia cell suspension and tomentin administered via the oral route on the left joint after 10 days of $\mathrm{K} / \mathrm{C}$-induced edema.

\begin{tabular}{|l|c|c|c|}
\hline Treatment & $\begin{array}{c}\text { Dose } \\
\text { (mg/kg) }\end{array}$ & Edema (mm) & $\begin{array}{c}\text { Edema } \\
\text { inhibition (\%) }\end{array}$ \\
\hline $\begin{array}{l}\text { Negative control } \\
\text { (vehicle) }\end{array}$ & - & $2.25 \pm 0.13$ & - \\
\hline $\begin{array}{l}\text { Physiological saline } \\
\text { solution (PSS) }\end{array}$ & - & 0 & - \\
\hline Methotrexate & 5.0 & $1.01 \pm 0.08^{* *}$ & 55 \\
\hline SaDM extract & 100.0 & $0.63 \pm 0.10^{* *}$ & 72 \\
\hline Tomentin & 5.0 & $1.55 \pm 0.03^{* *}$ & 31 \\
\cline { 2 - 4 } & 10.0 & $1.36 \pm 0.06^{* *}$ & 40 \\
\cline { 2 - 4 } & 15.0 & $0.81 \pm 0.09^{* *}$ & 64 \\
\cline { 2 - 4 } & 20.0 & $0.61 \pm 0.08^{* *}$ & 73 \\
\hline
\end{tabular}

Mean \pm SEM $(n=12) .{ }^{*}$ Edema volumes significantly different

$(p<0.0001)$ according to the Dunnett test mation continuously decreased until day 9 ( $\triangleright$ Table 1$)$. Redness of the leg was minimal, and its appearance was similar to that prior to the damage being caused.

In mice treated with pure tomentin compound, at $5.0 \mathrm{mg} / \mathrm{kg}$, joint edema increased during the first 6 days $(1.79 \pm 0.03 \mathrm{~mm})$, without reaching the edema volume of the negative control group. In mice treated with 10.0 and $15.0 \mathrm{mg} / \mathrm{kg}$, the initial edema that formed remained until day $5(1.68 \pm 0.06$ and $1.47 \pm 0.10 \mathrm{~mm}$, respectively), after which it declined ( $\triangleright$ Table 1). Only at the $20.0 \mathrm{mg} /$ $\mathrm{kg}$ dose did the joint edema in the mice decrease from day 1 of treatment until day 9 ( $\triangleright$ Fig. 2 and $\triangleright$ Table 1). Administration of methotrexate, SaDM extract, and tomentin caused a significant decrease of articular edema when treatments were compared with the negative control group $(p<0.0001)$. Tomentin exhibited dosedependent inhibition of joint edema induced with $\mathrm{K} / \mathrm{C}$ ( $\vee$ Table 1$)$, with a median $\mathrm{ED}_{50}$ of $10.32 \mathrm{mg} / \mathrm{kg}$ (Fig. 1S, Suppporting Information). All groups of mice treated with tomentin showed no cracks in the legs, and no yellowish fluid secretion was observed.

The mean BW of mice in the PSS group increased during the study period, with a weight gain at day 9 ( $\triangleright$ Table 2 ). Articular administration of $\mathrm{K} / \mathrm{C}$ caused a decrease in the BW of mice gradually, until day 9. Methotrexate-administered animals also tended to lose weight in a similar manner to that of the negative control group. According to the Student's t-test, the average weight loss at day 9 was superior $(p<0.0001)$ to that of the negative control. In contrast, in mice treated with the SaDM extract at $100.0 \mathrm{mg} / \mathrm{kg}$, a lost weight was observed during the first 2 days $(-1.92 \pm 0.17 \mathrm{~g})$, with a tendency to recover this from day 3 . After 9 days, the weight loss was not statistically different from the negative control group. Mice treated with $5.0,10.0,15.0$, and $20.0 \mathrm{mg} / \mathrm{kg}$ of tomentin showed a weight reduction only on day 1 of the induced damage, with a tendency to recover it. Weight loss in the group treated with $5.0 \mathrm{mg} / \mathrm{kg}$ was statistically lower than that registered in the negative control group (Student's t-test, $p<0.0001$ ). In the groups treated with $10.0,15.0$ and $20.0 \mathrm{mg} / \mathrm{kg}$, there was a slight increase in the BW. Nevertheless, the weight gain was lower than that of the PSS group ( $\triangleright$ Table 2 ).

To understand how the SaDM extract and tomentin exert their effects on arthritis, immunoanalyses were performed to examine the participation of inflammatory (TNF- $\alpha$ and IL-1 $\beta$ ) and anti-inflammatory (IL-4 and IL-10) cytokines in joint tissue derived from K/C-induced arthritic mice with or without treatment. Carrageen-

- Table 2 Effect of SaDM extract from the biomass of S. angustifolia cell suspension and tomentin administered via the oral route on BW after 10 days of $\mathrm{K} / \mathrm{C}$-induced edema.

\begin{tabular}{|c|c|c|c|c|}
\hline Treatment & Dose $(\mathrm{mg} / \mathrm{kg})$ & Body weight (day 0 ) & Body weight (day 9) & Weight differences $(g)$ \\
\hline Negative control (vehicle) & - & $30.52 \pm 2.58$ & $29.02 \pm 1.78$ & $-2.40 \pm 0.29$ \\
\hline Physiological saline solution (PSS) & - & $28.06 \pm 2.87$ & $30.34 \pm 2.50$ & $2.28 \pm 0.16$ \\
\hline Methotrexate & 5.0 & $30.18 \pm 2.85$ & $25.83 \pm 2.81$ & $-4.35 \pm 0.47^{* *}$ \\
\hline SaDM extract & 100.0 & $31.29 \pm 1.39$ & $30.10 \pm 1.24$ & $-1.19 \pm 0.17$ \\
\hline \multirow[t]{4}{*}{ Tomentin } & 5.0 & $28.90 \pm 1.57$ & $27.59 \pm 1.83$ & $-1.31 \pm 0.19^{* *}$ \\
\hline & 10.0 & $27.60 \pm 2.16$ & $27.78 \pm 2.2 .23$ & $0.18 \pm 0.03^{* *}$ \\
\hline & 15.0 & $27.28 \pm 1.74$ & $27.70 \pm 1.22$ & $0.42 \pm 0.08^{* *}$ \\
\hline & 20.0 & $29.74 \pm 2.26$ & $30.65 \pm 1.88$ & $0.91 \pm 0.06^{* *}$ \\
\hline
\end{tabular}




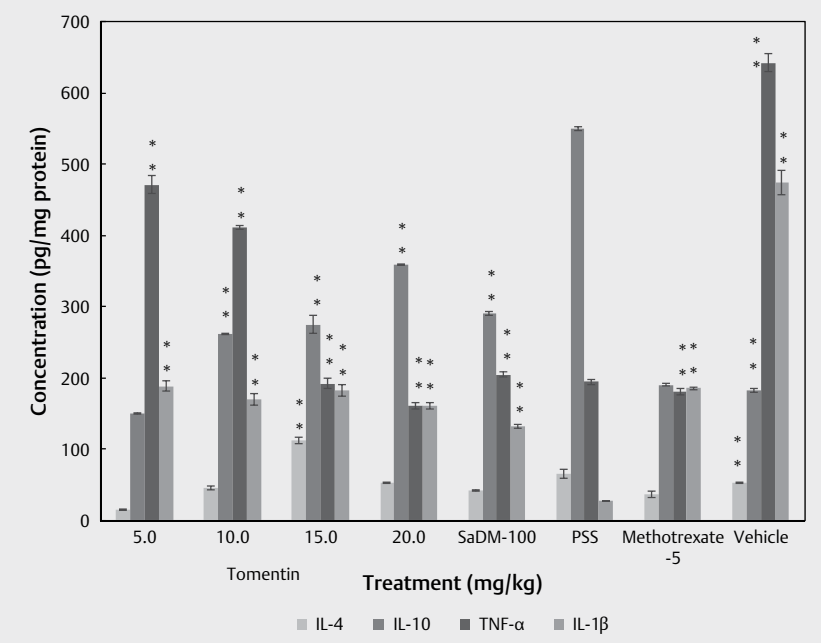

- Fig. 3 Effect of SaDM and tomentin from S. angustifolia cell suspensions on tumor necrosis factor alpha (TNF- $\alpha$ ), interleukin- 1 beta $(\mathrm{IL}-1 \beta), \mathrm{IL}-4$, and IL-10 in joint edema in mice induced with $\mathrm{K} / \mathrm{C}$. Each bar represents the mean $\pm S E M, n=4$. ${ }^{*}$ Means represent differences of the treatment groups compared with the negative control group according to Student's t-test $(p<0.0001)$ and differences of the negative control group compared with the PSS group according to the Student's t-test $(p<0.0001)$.

an promoted a significant increase of TNF- $\alpha$ and IL-1 $\beta$ concentration in comparison to the healthy (SSE) mice. On the other hand, the content of anti-inflammatory cytokines IL-4 and IL-10 ( $\triangleright$ Fig. 3) decreased significantly. In animals treated with $5 \mathrm{mg} / \mathrm{kg}$ methotrexate daily, levels of pro-inflammatory cytokines TNF- $\alpha$ and IL-1 $\beta$ decreased in joints when compared with the negative control group. The content of anti-inflammatory cytokines IL-4 and IL-10 ( Fig. 3) did not improve.

In the group treated with the SaDM extract at a dose of $100 \mathrm{mg} /$ $\mathrm{kg}$, TNF- $\alpha$ and IL-1 $\beta$ levels were statistically lower than that presented in the negative control. Furthermore, TNF- $\alpha$ levels were similar to those detected in the healthy mice. The SaDM extract did not give rise to significant changes to the $\mathrm{K} / \mathrm{C}$ group in IL-4 joint levels. However, the SaDM extract was able to increase IL-10 levels relative to the negative control ( $\vee$ Fig. 3 ).

In mice treated with tomentin, pro-inflammatory TNF- $\alpha$ levels were lower than those of the negative control group. This effect depended on the dose administered. At the $20-\mathrm{mg} / \mathrm{kg}$ dose, the content of this cytokine was statistically similar than that of mice treated with methotrexate ( $\vee$ Fig. 3 ). In all groups receiving tomentin, the IL-1 $\beta$ levels were statistically lower than that of the negative control, and no dose-dependent effect was observed. In addition, the cytokine levels were similar to those of mice treated with methotrexate. The results showed that cytokine IL-4 and IL-10 levels increase with increasing doses of tomentin ( $\vee$ Fig. 3 ).

\section{Discussion}

Cell suspension culture is an excellent technique to produce scopoletin, the active compound identified in the wild plant of $S$. angustifolia as well as tomentin and sphaeralcic acid anti-inflam- matory compounds. The SaDM extract from S. angustifolia cell suspension is capable of diminishing the edema development induced by diverse irritating agents, such as TPA or $\lambda$-carrageenan $[9,10]$. However, the SaDM extract and tomentin in the rheumatoid-related diseases treatment remains unknown. With this purpose in mind, the present study was designed based on the disease course of $\mathrm{K} / \mathrm{C}$-induced arthritis.

Rheumatoid arthritis is a symmetric polyarticular arthritis that primarily affects small diarthrodial joints of the hands and feet [11]. $\mathrm{K} / \mathrm{C}$-induced arthritis is used as an animal model of human rheumatoid arthritis, which is difficult to assess in human systems [12]. The arthritis-like signs of $\mathrm{K} / \mathrm{C}$-induced arthritis in mice resemble several histopathological features of human rheumatoid arthritis, including mononuclear cell infiltration and synoviocyte hyperplasia, resulting in pannus formation followed by bone and cartilage destruction $[13,14]$. Joint inflammation in experimental arthritis induced with $\mathrm{K} / \mathrm{C}$ in mice exhibited maximal joint edema in the first $24 \mathrm{~h}$ accompanied by an exudate [15]. Methotrexate has long been used in the treatment of rheumatoid arthritis and it has significantly inhibited joint edema, but the mean BW of these mice dropped, which may be one of the side effects of methotrexate. The SaDM extract also inhibited joint edema in $\mathrm{K} / \mathrm{C}$-induced mouse arthritis, demonstrating only redness in the left joint. This effect was higher than that reported for the dichloromethane extract of the wild plant administered via the intraperitoneal route at the same dose in the model of chronic inflammation with CFA [8]. The BW lost in mice treated with the SaDM extract was similar than that of the $\mathrm{K} / \mathrm{C}$ group.

The SaDM extract to $100 \mathrm{mg} / \mathrm{kg}$ and tomentin to $20 \mathrm{mg} / \mathrm{kg}$ had the highest anti-inflammatory activity. During the whole period of tomentin administration, the joint edema size decreased progressively. This phenomenon was only observed during the first 5 days of SaDM extract administration, while at this time, the extract effect was lower than that observed by tomentin. Subsequently, there was a rapid decrease in the joint edema (biphasic effect) and at the last day of treatment with the SaDM extract had a similar effect to that of tomentin. Each $100 \mathrm{mg}$ of SaDM extract contains $0.10 \mathrm{mg}$ of scopoletin, $0.10 \mathrm{mg}$ of tomentin, and $0.19 \mathrm{mg}$ sphaeralcic acid (Fig. 2S, Supporting Information). The amount of tomentin administered in the SaDM extract $(100 \mathrm{mg} / \mathrm{kg})$ was much lower than when given only tomentin $(20 \mathrm{mg} / \mathrm{kg})$. This phenomenon can be seen as a dose-dependent effect. In addition, the chemical content of the SaDM extract is complex and it could exert anti-inflammatory activity by different mechanisms of action associated with the compounds already identified and the presence of others. Scopoletin, for example, possesses a wide range of pharmacological activities [16-19]. Scopoletin was isolated from S. angustifolia and E. obtusifolia, and the anti-inflammatory effects have already been evaluated in TPA-induced mouse ear edema $[8,19]$. In rat CFA-induced arthritis, intraperitoneal administration of scopoletin dosedependently reduced both inoculated and non-inoculated joint edema, and elevated the mean BW [20]. Scopoletin was capable of ameliorating synovial hyperplasia, reduced the presence of inflammatory cells in the synovium, and diminished erosive changes in cartilage and bone in addition to exhibiting angiogenesis inhibition. Also, scopoletin selectively inhibited the overexpression of IL- 6 rather than TNF- $\alpha$ or IL- $\beta$ in synovial tissues of rats with CFAinduced arthritis [20]. 
Tomentin also inhibited both inoculated and non-inoculated joint edema in $\mathrm{K} / \mathrm{C}$-induced mouse arthritis and the BW loss was similar to that of the $\mathrm{K} / \mathrm{C}$-induced arthritis group. The anti-inflammatory effect of tomentin is dependent on its coumaric origin. It has been reported that various compounds of this group, natural or synthetic, act as inhibitors of the cyclooxygenase and lipoxygenase enzymes, which modulate the biosynthesis of prostaglandins and leukotrienes, respectively, with the latter participating in the process of chronic inflammation [21].

Injection of $2 \%$ carrageenan into the knee joint in rats promotes the activation of macrophages, dendritic cells, and lymphocytes. These cells in turn produce TNF- $\alpha$, IL-1 $\beta$ and IL-6, and other cytokines that are responsible for the inflammatory response. Once the focus of damage is localized, the production of pro-inflammatory cytokines ceases and the production and release of anti-inflammatory cytokines such as IL- 4 and IL- 10 begins, with the latter in turn disabling the effector cells $[14,15]$. In the results presented here, it was observed that intra-articular administration of $\mathrm{K} / \mathrm{C}$ caused widespread damage in mice due to the rise in the proinflammatory cytokine (TNF- $\alpha$ and IL-1 $\beta$ ) levels and a decrease in the levels of anti-inflammatory cytokines (IL-4 and IL-10).

It has been mentioned that carrageenan-induced arthritis models possess many features of human rheumatoid arthritis. The administration of this substance resulted in localized inflammation associated with the production of a number of mediators such as TNF- $\alpha$ and IL-1 $\beta$ [22]. In a study in our laboratory, it has been shown that the intra-articular administration of carrageenan, as an experimental procedure, induced an important local increment of TNF- $\alpha$ and IL-1 [23]. It has been demonstrated that TNF- $\alpha$ induces cartilage and bone degradation, and the penetration of lymphocytes, macrophages, and neutrophils to the joint cavity. IL-1 $\beta$ in vitro induces cytokine production by synovial mononuclear cells, and when it is blocking IL-1 $\beta$ and components of the receptor for IL-1 $\beta$, it has been shown to be effective in reducing inflammation and, particularly, articular damage in several rodent models of rheumatoid arthritis. These pro-inflammatory cytokines and interleukins are involved in osteoclast differentiation, inflammation, and bone erosion [24], enhance the synthesis of metalloproteinases and proliferation of synovial cells resulting in cartilage degradation [25], and are capable of stimulating the production and secretion of other cytokines such as IL-6, which also promotes cartilage degradation. In the $\mathrm{K} / \mathrm{C}$-induced arthritis animal model, this cytokine was also elevated in the articulation [22]. While IL-4 and IL-10 are regulators that control the progression of rheumatoid arthritis, the level of these interleukins may lead to protection in order to prevent cartilage destruction and bone erosion [26].

The SaDM extract and tomentin were also capable of modulating cytokine concentrations. IL-1 $\beta$ and TNF- $\alpha$ levels decrease, accompanied by an increase of interleukins IL-4 and IL-10, activity that can prevent the damage induced by $\mathrm{K} / \mathrm{C}$ controlling the inflammation and progression of rheumatoid arthritis. The reduction of TNF- $\alpha$ and increase of IL-10 was tomentin doses-dependent. In rats with CFA-induced arthritis and treated with the dichloromethane extract of the aerial parts from the $S$. angustifolia wild plant, the levels of pro-inflammatory interleukins IL- $1 \beta$ and IL- 6 were also reduced. Furthermore, the anti-inflammatory cytokine IL-10 level was increased [7]. It is proposed that IL-10 has a down- regulation activity on the levels of the pro-inflammatory cytokines like TNF- $\alpha$.

The histopathology analyses for the dichloromethane:methanol extract and tomentin are a perspective of this experimental project. It will also be important to isolate and identify other components with anti-inflammatory activity in the SaDM extract, as well as to evaluate the effect of sphaeralcic acid and the interaction of the active compounds identified in the extract to determine if there is synergy in their effects in the $\mathrm{K} / \mathrm{C}$-induced arthritis animal model. These advances are important for the development of a phytomedication with the standardized SaDM extract in the active components for a clinical trial.

\section{Materials and Methods}

\section{Plant material}

Plants and fruits of Vara de San Jose plants were collected in Hidalgo State, Mexico. Plant samples were authenticated by Abigail Aguilar, M.Sc., Head of the Herbarium at the Instituto Mexicano del Seguro Social in Mexico City [IMSSM], as S. angustifolia, and vouchers were stored for reference under \#14294.

\section{Plant cell culture}

Suspension-cultured cells in batches of $S$. angustifolia were grown in $250 \mathrm{~mL}$ flasks with $80 \mathrm{~mL}$ of whole MS liquid medium [27], with $27.4 \mathrm{mmol}$ of total nitrates $\left(\mathrm{NH}_{4} \mathrm{NO}_{3} 15.9 \mathrm{mmol}\right.$, and $\mathrm{KNO}_{3}$ $11.5 \mathrm{mmol}$ ) supplied with $1 \mathrm{mg} / \mathrm{L}$ of $\alpha$-naphthalene acetic acid in combination with kinetin $(0.1 \mathrm{mg} / \mathrm{L})$ and supplemented with $30 \mathrm{~g} / \mathrm{L}$ of sucrose. The flasks were placed in an orbital shaker at $110 \mathrm{rpm}$ (New Brunswick Scientific Co., Inc.) and incubated at $26 \pm 2{ }^{\circ} \mathrm{C}$ during a light:dark (16h:8 h) photoperiod under $50 \mu \mathrm{M} / \mathrm{m}^{2} / \mathrm{sec}$ warm white fluorescent light intensity (9-10). The biomasses were changed to fresh medium under sterile conditions every 16 days, utilizing an inoculum of $4 \%(\mathrm{w} / \mathrm{v})$ of fresh biomass.

\section{Stimulation of scopoletin, tomentin, and sphaeralcic acid production}

Utilizing the same inoculum, cell suspensions cultivated in whole MS medium were transferred into $1 \mathrm{~L}$ flasks with $400 \mathrm{~mL}$ of MS medium, with the total nitrate concentration reduced to $2.74 \mathrm{mmol}$ $\left(\mathrm{NH}_{4} \mathrm{NO}_{3} 1.59 \mathrm{mmol}\right.$, and $\left.\mathrm{KNO}_{3} 1.15 \mathrm{mmol}\right)$ and were incubated under previously described conditions. Cultures were arrested on day 16 of the culture to obtain the biomass $[9,10]$.

\section{Extraction and tomentin isolation}

Suspension-cultured cells from flasks were filtered and the biomasses were pooled and dried at room temperature. Then, the dry biomass was extracted 3 times by maceration at room temperature with a mixture of grade-reactive solvent $\left(\mathrm{CH}_{2} \mathrm{Cl}_{2}: \mathrm{CH}_{3} \mathrm{OH}\right.$ 9: 1; Merck) at a ratio of $1: 20(\mathrm{w} / \mathrm{v})$ at $24 \mathrm{~h}$ for each. The dichloromethane-methanol extracts were filtered, pooled, and concentrated to dryness under reduced pressure. The scopoletin, tomentin, and sphaeralcic acid content in the SaDM extract was determined by HPLC $[9,10]$.

To purify the tomentin compound, the SaDM extract was fractionated by silica gel column chromatography $(9 \times 28 \mathrm{~cm}, 70-230$ mesh; Merck) using an n-hexane-ethyl acetate-methanol gradient system 
(grade-reactive solvents; Merck) with $5 \%$ polarity increments. Aliquots of $500 \mathrm{~mL}$ were collected, and samples with a similar TLC profile were integrated into 10 fractions (1-10). The fraction with tomentin was through an open silica gel RP- 18 column $(1.5 \times 28 \mathrm{~cm}, 40-63$ mesh; Merck) with an $\mathrm{H}_{2} \mathrm{O}: \mathrm{CH}_{3} \mathrm{CN}$ elution system (grade-reactive solvents; Merck) with an increasing polarity of $10 \%$, and the compound was isolated from pooled subfractions (70:30, $\mathrm{H}_{2} \mathrm{O}: \mathrm{CH}_{3} \mathrm{CN}$ ) [9]. The structure of tomentin was confirmed by comparison of spectroscopic data (Table 1S, Supporting Information) ${ }^{1} \mathrm{H}$ NMR [9].

\section{HPLC conditions}

HPLC analyses were carried out in a Waters system (2 695 Separation Module) coupled to a diode array detector (2996) with a 190$600 \mathrm{~nm}$ detection range and operated by the Manager Millennium software system (Empower 1; Waters Corp.). Separations were performed in a Spherisorb ${ }^{\circledR} \mathrm{RP}-18$ column $(250 \times 4.6 \mathrm{~mm}, 5 \mu \mathrm{m}$; Waters) employing a constant temperature of $25^{\circ} \mathrm{C}$ during analyses. Samples $(20 \mu \mathrm{L})$ were eluted at a $1.2 \mathrm{~mL} / \mathrm{min}$ flow rate with (A) highpurity $\mathrm{H}_{2} \mathrm{O}$ (TFA-1.0\%) and (B) high-purity $\mathrm{CH}_{3} \mathrm{CN}$ gradient mobile phases (Merck), and were detected by monitoring absorbance at $340 \mathrm{~nm}$. The mobile phase was started with water (100\%) and was maintained for $1 \mathrm{~min}$. Then, the concentration of solvent $B$ was gradually increased to $15 \%$ (at $1 \mathrm{~min}$ ), $37 \%$ (at $10 \mathrm{~min}$ ), and $85 \%$ (at 2 min). During the next 2 min, solvent B was increased to $100 \%$ and this proportion was maintained for 3 min. Finally, the next 3 min were utilized to return the mobile phase to the initial condition. The chromatographic method had a 22-min run time. Calibration curves were constructed with a standard solution of 2,4 , 8,12 and $16 \mu \mathrm{g} / \mathrm{mL}$. Scopoletin presented a regression equation of $Y=21985(X)-117889$ and $R^{2}=0.9997$, while for tomentin theses were $Y=46018(X)-394683$ and $R^{2}=0.9992$ and for sphaeralcic acid, these were $Y=2576(X)-23696$ and $R^{2}=0.9996$. The retention times (rt) of compounds tomentin at $\lambda=343 \mathrm{~nm}$ ( $\geq 93 \%$ ), scopoletin at $\lambda=343 \mathrm{~nm}$ ( $99 \%$; Sigma-Aldrich Química México), and sphaeralcic acid ( $\geq 98 \%$ ) at $\lambda=357 \mathrm{~nm}$ were $13.37 \mathrm{~min}, 13.65$, min and $18.00 \mathrm{~min}$, respectively. Sphaeralcic acid was isolated and purified at our Laboratory from $S$. angustifolia cell suspensions according to the procedure already reported [9]. Compound identifications were performed by comparing their rt and absorbance spectra $[9,10]$.

\section{Animals}

We used ICR outbred-strain female mice weighting $25.0-30.0 \mathrm{~g}$ each. The experiments were performed according to Mexican Official Norm 062-ZOO-1999 (Technical Specifications for the Production, Care and Use of Laboratory Animals) and international ethical guidelines for the care and use of laboratory animals. The animals were maintained at a temperature of $22 \pm 3^{\circ} \mathrm{C}, 70 \pm 5 \%$ humidity, and 12-h/12-h light/dark cycles with water and food ad libitum.

The experimental protocol was evaluated by the committee CLIEIS-1701 (Comité Local de Investigación y Ética en Investigación y Salud) from the Instituto Mexicano del Seguro Social (IMSS, Mexico), and approved January 1, 2011, with the register number 20111701-3.

\section{Arthritis model induced by kaolin/carrageenan}

This experimental design lasted 10 days. There were 8 groups of 12 mice each as follows: initially, measurements were taken from the baseline size of the left joint with a Mitutoyo-brand digital micrometer (Micrometric Digimatic Calibration MDC-1"SB; Mitutoyo Products). Then, the animals were anesthetized with pentobarbital sodium administered i.p. at a dose of $55 \mathrm{mg} / \mathrm{kg}$. Later, these mice were slowly injected with a kaolin $(4 \%, 40 \mu \mathrm{L})$ solution in the joint cavity of the left knee. Consecutively, flexions and extensions were performed during $15 \mathrm{~min}$ in the joint administered with the drug. Immediately, the mice were injected in the same left knee joint cavity with $40 \mu \mathrm{L}$ of carrageenan at $2 \%$. Similarly, flexions were carried out for an additional 5 min [28].

Administration of the treatments was conducted each day by oral route, and was initiated 1 day after damage induction until day 10 (9 days of treatment). The negative control group (group 1 ) received oral administration of the vehicle without any drugs (negative control); the positive control group (group 2) was administered with $5.0 \mathrm{mg} / \mathrm{kg}$ of methotrexate ( $\geq 98 \%$ purity; Sigma-Aldrich Química México). In group 3, mice were treated with $100 \mathrm{mg} / \mathrm{kg}$ of SaDM extract standardized in its content of scopoletin, tomentin, and sphaeralcic acid, according to previous reports of dichloromethane-methanol extract from cell suspension biomasses evaluated in acute inflammation models and $\mathrm{DE}_{50}$ determined in a subplantar edema model in mice. In groups 4, 5, 6, and 7, mice were treated with $5.0,10.0,15.0$, and $20.0 \mathrm{mg} / \mathrm{kg}$, respectively, of tomentin ( $93 \%$ purity). A baseline group of healthy animals was also employed. These animals were injected with PSS into the left joint (group 8) as a substitute of K/C.

Each day, BW and left joint size ( $\mathrm{mm}$ ) in the controls and treated groups were determined with respect to the baseline size of the left knees, and the percentage of inhibition of edema development was calculated utilizing the following formula:

Inhibition $\%=\left[\left(\frac{\text { negative control edema }- \text { treatment edema }}{\text { negative control edema }}\right) \times 100\right]$.

\section{Homogenization of joint tissue}

The left joint was liquefied to a temperature of $4^{\circ} \mathrm{C}$ and, under this condition, the samples were manipulated for analysis. The bone tissue was placed into a mortar and covered with dry ice. Then, the tissue was pulverized and completely disintegrated until the dry ice was sublimated. The disintegrated tissue was placed in a vial with $2 \mathrm{~mL}$ of PBS (pH 7.4) with phenylmethylsulfonyl fluoride at $0.01 \%$ dissolved in isopropyl alcohol (Merck, México). The joint was completely homogenized with a T-10 Ultra Turrax Homogenizer during $15 \mathrm{~s}$ for its disintegration. It was allowed to rest for $30 \mathrm{~s}$, and the procedure was repeated 5 additional times [29]. Afterward, the samples were placed into a centrifuge at $14000 \mathrm{rpm}$ for $5 \mathrm{~min}$. We obtained $300 \mu \mathrm{L}$ aliquots in centrifuged microtubes, which were immediately stored at $-70^{\circ} \mathrm{C}$ for cytokine analyses.

\section{Cytokine analyses}

Quantification of cytokines IL-1 $\beta$, TNF- $\alpha$, IL-10, and IL-4 was car-

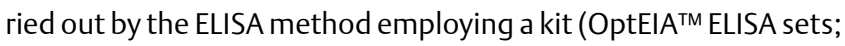
BD Biosciences) and following the manufacturer's instructions. On 96-well plates, $100 \mu \mathrm{L} /$ well of the antibody were added and incubated for $12 \mathrm{~h}$ at $4{ }^{\circ} \mathrm{C}$. Once this time had elapsed, the plate was washed 3 times with $300 \mu \mathrm{L} /$ well of PBS buffer. Subsequently, $100 \mu \mathrm{L}$ of PBS with FBS at $10 \%$ and $\mathrm{pH} 7.0$ were added and preserved 
during $1 \mathrm{~h}$ at room temperature. The contents were discarded and the plate was washed 3 times with $300 \mu \mathrm{L} /$ well of PBS buffer. Finally, $100 \mu \mathrm{L}$ of the standard, target (PBS with FBS), and test samples were added to the corresponding wells. The plate was incubated for $2 \mathrm{~h}$ at room temperature. The contents were discarded and the plate was washed 3 times with $300 \mu \mathrm{L} /$ well of PBS buffer. For TNF$\alpha$, IL-4, and IL-10, $100 \mu \mathrm{L} /$ well of antibody detection were added plus a streptavidin-horseradish peroxidase enzyme, which was incubated for $1 \mathrm{~h}$. After that, the plate was washed 7 times with $300 \mu \mathrm{L} /$ well of PBS buffer.

For IL-1 $\beta, 100 \mu \mathrm{L} /$ well of antibody detection were added, which was incubated for $1 \mathrm{~h}$ and washed with PBS $0.05 \%$ of Tween 20 , $300 \mu \mathrm{L} /$ well 5 times, followed by the streptavidin-horseradish peroxidase enzyme ( $100 \mu \mathrm{L} /$ well), which was incubated at room temperature and washed with PBS $0.05 \%$ of Tween $20,300 \mu \mathrm{L} /$ well 7 times.

For all cytokines, $100 \mu \mathrm{L}$ with $O$-phenylendiamine substrate (1 OPD tablet with 1 of urea dissolved in $20 \mathrm{~mL}$ of distilled water) were added to the wells. These ELISA plaques were incubated for $30 \mathrm{~min}$ at room temperature, under total darkness, and then a stop solution $\left(2 \mathrm{~N} \mathrm{H}_{2} \mathrm{SO}_{4}\right)$ was added. Each plaque was read at a $450 \mathrm{~nm}$ wavelength in a Stat Fact Awareness Technologies 2100 spectrophotometer.

\section{Statistical analysis}

Data obtained from joint edema (inhibition \%) in the left joints and BW were analyzed by one-way analysis of variance (ANOVA), and $p$ values of $\leq 0.05$ were considered significant. For joint edema and BW, significant differences among treatment means were calculated by the Dunnett ${ }_{0.05}$ test. For cytokines (pro- and anti-inflammatory) levels, Student's t-test was applied to compare each treatment vs. the negative control.

\section{Acknowledgments}

This work was supported by Basic Grant 513546 from the Consejo Nacional de Ciencia y Tecnología, México (CONACyT-México) for the master studies of Jade Serrano-Román at the Molecular Medicine Program of Morelos State Autonomous University, and by Complementary Grant 99186328 from the Instituto Mexicano del Seguro Social (IMSS, México). The research had financial support grants provided by FIS-IMSS/PROT/TMD14/1349.

\section{Conflicts of Interest}

The authors declare no conflict of interest.

\section{References}

[1] Scott DL, Wolfe F, Huizinga TW. Rheumatoid arthritis. Lancet 2010; 376: 1094-1108

[2] Smolen JS, Aletaha D, Koeller M, Weisman MH, Emery P. New therapies for the treatment of rheumatoid arthritis. Lancet 2007; 370: 1861-1874
[3] Martínez M. Catálogo de nombres vulgares y científicos de plantas Mexicanas, Ediciones Botas. Distrito Federal, México: Fondo de la Cultura Económica; 1979: 429

[4] Aguilar A, Camacho JR, Chino S, Jácquez P, López ME. Herbario medicinal del instituto Mexicano del seguro social. Distrito Federal, México: Instituto Mexicano del Seguro Social; 1994: 140: 251

[5] Calderón-Rzedowski G, Rzedowski J. Flora fanerogámica del Valle de México. Pátzcuaro, Michoacán, México: Instituto de Ecología, A.C. y Comisión Nacional para el Conocimiento y Uso de la Biodiversidad 2001; 393-395: 406-408

[6] Meckes M, David-Rivera AD, Nava-Aguilar V, Jiménez A. Activity of some Mexican medicinal plant extracts on carrageenan-induced rat paw edema. Phytomedicine 2004; 11: 446-451

[7] Juárez-Ciriaco M, Román-Ramos R, González-Márquez H, MeckesFischer M. Efecto de Sphaeralcea angustifolia sobre la expresión de citocinas pro y antiinflamatorias. LabCiencia 2008; 2: 21-23

[8] García-Rodríguez RV, Chamorro-Cevallos G, Siordia G, Jiménez-Arellanes A, Chávez-Soto MA, Meckes-Fischer M. Sphaeralcea angustifolia (Cav.) G. Don extract, a potential phytomedicine to treat chronic inflammation. Bol Latinoam Caribe Plant Med Aromat 2012; 11: 454-463

[9] Pérez-Hernández J, González-Cortazar M, Marquina S, Herrera-Ruiz M, Meckes-Fischer M, Tortoriello J, Cruz-Sosa F, Nicasio-Torres M, del P. Sphaeralcic acid and tomentin anti-inflammatory compounds produced in cell suspension cultures of Sphaeralcea angustifolia. Planta Med 2014; 80: 209-214

[10] Nicasio-Torres P, Pérez-Hernández ], González-Cortazar M, MeckesFischer M, Tortoriello J, Cruz-Sosa F. Production of potential antiinflammatory compounds in cell suspension cultures of Sphaeralcea angustifolia (Cav.) G. Don. Acta Physiol Plant 2016; 38: 209-219

[11] Firestein GS. Evolving concepts of rheumatoid arthritis. Nature 2003; 423: 356-361

[12] Bendele A. Animal models of rheumatoid arthritis. J Musculoskelet Neuronal Interact 2001; 1: 377-385

[13] Bhattacharyya S, Dudeja PK, Tobacman JK. Tumor necrosis factor alpha-induced inflammation is increased but apoptosis is inhibited by common food additive carrageenan. J Biol Chem 2010; 285: 39511-39522

[14] Achari Y, Reno CR, Frank CB, Harta DA. Carrageenan-induced transient inflammation in a rabbit knee model: Molecular changes consistent with an early osteoarthritis phenotype. Inflamm Res 2012; 61: 907-914

[15] Gaitán G, Herrero J. Subanalgesic doses of dexketoprofen and HCT-2037 (nitrodexketoprofen) enhance fentanyl antinociception in monoarthritic rats. Pharmacol Biochem Behav 2005; 80: 327-332

[16] Farah MH, Samuelsson G. Pharmacologically active phenylpropanoids from Senra incania. Planta Med 1992; 58: 14-18

[17] Silván AM, Abad M], Bermejo P, Sollhuber M, Villar A. Anti-inflammatory activity of coumarins from Santolina oblongifolia. J Nat Prod 1996; 59: 1183-1185

[18] Muschietti L, Gorzalcsny S, Ferraro G, Acavedo C, Martino V. Phenolic compounds with anti-inflammatory activity from Eupatorium buniifolium. Planta Med 2001; 67: 743-744

[19] Ding Z, Dai Y, Hao H, Pan R, Yao X, Wang Z. Antiinflammatory effects of scopoletin and underlying mechanisms. Pharm Biol 2009; 46: 557-566

[20] Pan R, Gao XH, Li Y, Xia YF, Dai Y. Anti-arthritic effect of scopoletin, a coumarin compound occurring in Erycibe obtusifolia Benth stems, is associated with decreased angiogenesis in synovium. Fundam Clin Pharmacol 2010; 24: 477-490

[21] Fylaktakidou KC, Hadjipavlou-Litina DJ, Litinas KE, Nicolaides DN. Natural and synthetic coumarin derivatives with anti-inflammatory/ antioxidant activities. Curr Pharm Des 2004; 10: 3813-3833 
[22] Rocha CC, Fernández E, Quintao-Nara LM, Campos MM, Calixto JB. Relevance of tumor necrosis factor- $\alpha$ for the inflammatory and nociceptive responses evoked by carrageenan in the mouse paw. Br J Pharmacol 2006; 148: 688-695

[23] Salinas-Sánchez DO, Zamilpa A, Pérez S, Herrera-Ruiz M, Tortoriello ], González-Cortazar M, Jiménez-Ferrer E. Effect of hautriwaic acid isolated from Dodonaea viscosa in a model of kaolin/carrageenaninduced monoarthritis. Planta Med 2016; 81: 1240-1247

[24] Joosten LA, Helsen MM, Saxne T, van de Loo FA, Heinegard D, van den Berg WB. IL-1 alpha beta blockade prevents cartilage and bone destruction in murine type II collagen-induced arthritis, whereas TNF-alpha blockade only ameliorates joint inflammation. J Immunol 1999; 163: 5049-5055

[25] Niki Y, Yamada H, Kikuchi T, Toyama Y, Matsumoto H. Membrane associated IL-1 contributes to chronic synovitis and cartilage destruction in human IL-1 alpha transgenic mice. J Immunol 2004; 172: $577-584$
[26] Jorgensen C, Apparaill F, Couret I, Canovas F, Jacquet C, Sany ]. Interleukin-4 and interleukin-10 are chondroprotective and decrease mononuclear cell recruitment in human rheumatoid synovium in vivo. Immunology 1998; 93: 518-523

[27] Murashige T, Skoog F. A revised medium for rapid growth and bioassay with tobacco tissue culture. Plant Physiol 1962; 15: 473-497

[28] Neugebauer V, Li W. Differential sensitization of amygdala neurons to afferent inputs in model of arthritic pain. J Neurophysiol 2003; 89: 716-727

[29] Gong D, Chu W, Jiang L, Geng C, Li J, Ishikawa N, Kajima K, Zhong L. Effect of fucoxanthin alone and in combination with D-glucosamine hydrochloride on carrageenan/kaolin-induced experimental arthritis in rats. Phytother Res 2014; 28: 1054-1063 